\title{
Violent storms within the Sea: dense water formation episodes in the NW Mediterranean
}

\author{
J. Salat ${ }^{1}$, P. Puig ${ }^{1}$, and M. Latasa ${ }^{2}$ \\ ${ }^{1}$ Insitut de Ciències del Mar (CSIC), P. Marítim, 37-49, 08003 Barcelona, Spain \\ ${ }^{2}$ Centro Oceanográfico de Gijón (IEO), Avda. Príncipe de Asturias 70 bis, 33212 Gijón - Asturias, Spain
}

Received: 4 March 2010 - Revised: 29 March - Accepted: 13 April 2010 - Published: 7 July 2010

\begin{abstract}
Heat and water exchanges in the ocean occur almost exclusively at the surface. As water compressibility is very low, stratification of the fluid is expected and horizontal motion is predominant in the sea interior. Among the few processes that may introduce a vertical component in the water motion are those that increase surface water density by freezing, cooling or evaporation. Those processes triggering convective motion are enhanced by cold surface air, dry wind and low solar radiation. Therefore, convective cells are more likely to occur when the temperature of the air at the sea surface is lower than sea surface temperature. Conversely, rain, river runoff, solar heating, calm and condensation at surface enhance stratification. Convective motion at sea has several scales ranging from few meters at the upper ocean, causing the surface mixed layer, to the entire water column, in what is known as deep convection. Only few places in the world ocean are suitable for deep convection, and only under particular weather conditions. In this paper, a brief review of the response to these particular conditions in the NW Mediterranean is presented in what is known as dense water formation. The violent sinking and spreading of water parcels that reach the deep sea floor in few hours is described. These are "hidden" mediterranean storms, occurring under the sea surface, "on the other side of the mirror".
\end{abstract}

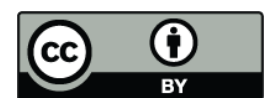

Correspondence to: J. Salat (salat@icm.csic.es)

\section{Introduction}

The Mediterranean Sea is a semi-enclosed basin open to the Atlantic Ocean through the Strait of Gibraltar. In terms of water budget for the whole Mediterranean, evaporation exceeds precipitation and runoff. It is thus a concentration basin. Water received from the surface is transformed within the basin and returned back to the ocean in two ways: (i) directly through Gibraltar ( $95 \%)$, with higher density (more than $2 \mathrm{~kg} / \mathrm{m}^{3}$ ), spreading at more than $1000 \mathrm{~m}$ depth into the Atlantic Ocean, and (ii) indirectly $(\sim 5 \%)$ as fresh water, transported by the atmosphere out of the Mediterranean catchment basin. Salinity of water outflow through Gibraltar is $\sim 1.7$ higher than inflow (Lacombe et al., 1981; Hopkins, 1978). However, evaporation is neither the only process that increases the water density nor it is a steady or uniform process. The factors affecting water density are temperature and salinity, which are driven by water and heat exchanges with the atmosphere. Therefore, changes in water density depend on water circulation and local weather conditions, both with seasonal and geographical constraints.

In the Mediterranean, during late summer, convective motions due to night cooling, breezes, and occasional wind storms start to form the surface mixed layer, whose thickness grows as autumn progresses. Along this season, the vertical scale of the mixing increases step by step, through wind storms and direct cooling (cold air and low solar radiation), breaking the thermocline, down to the bottom over the continental shelves, typically not deeper than $120 \mathrm{~m}$, in winter. However, as the Gibraltar sill is relatively shallow $(\sim 350 \mathrm{~m})$ in relation to the average Mediterranean basin (2000-3000 m), the stratification of the deeper layers is weak (Furnestin, 1960). Therefore, where and when the upper layer becomes well mixed, typically in mid winter and in the

Published by Copernicus Publications on behalf of the European Geosciences Union. 


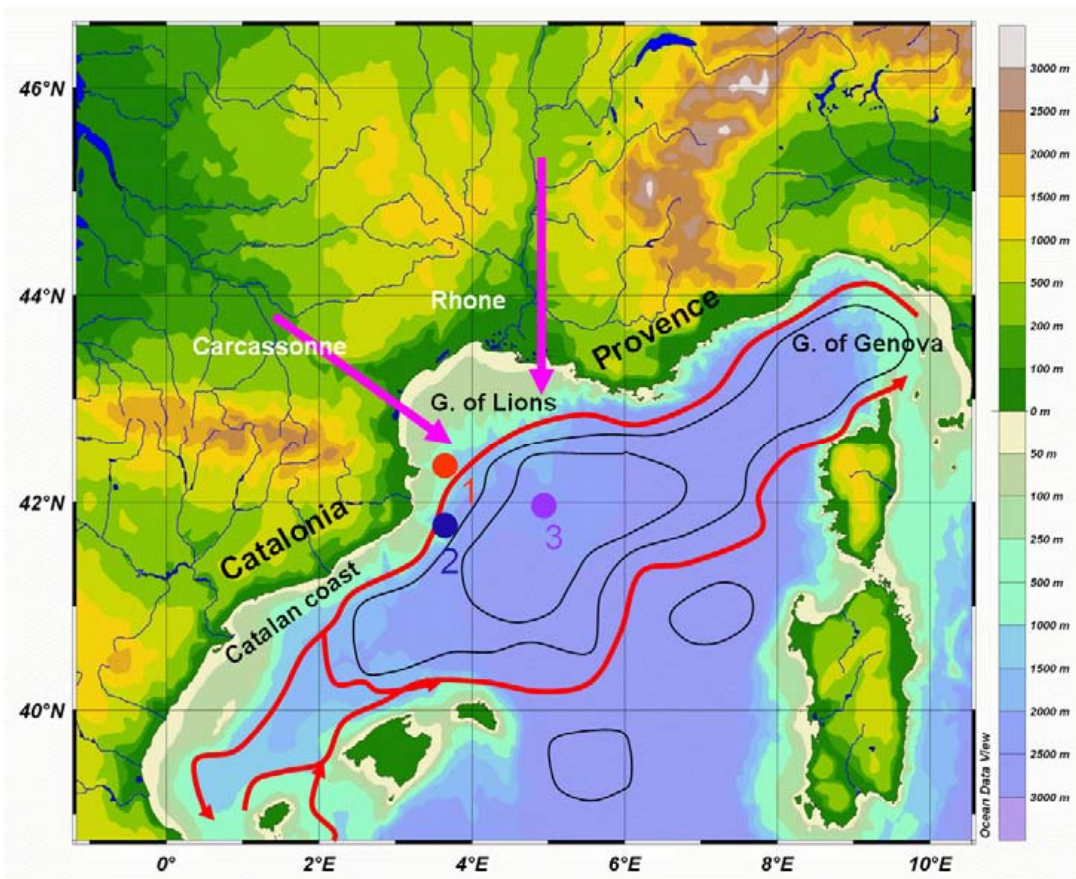

Fig. 1. Map of the NW Mediterranean basin showing its bathymetry and orography. Preferential paths of northerly winds (straight purple arrows) and scheme of the upper layer circulation (red lines and black streamlines) are also shown. The locations of the moorings from which time series are plotted in the next figures are indicated with 1 (canyon), 2 (slope) and 3 (basin), respectively with the same colour code as the corresponding time series.

northern regions, any extra loss of buoyancy by evaporation can cause, a priori, surface water to start sinking. During the last 50 years an effort in both observational and theoretical fields has been carried out to describe the specific mechanisms of ocean-atmosphere coupling, leading to dense water formation in the NW Mediterranean (MEDOC, 1970; Gascard, 1978; Leaman and Schott, 1991; etc). The complexity of the interactions and the response of the sea are still not completely uncovered because of the difficulties in observations that should be performed under very rough weather conditions and the problems of the models to deal with nonhydrostatic parameterization, a wide range of scales and abrupt shifts (e.g., Herrmann and Somot, 2008). Recently, an effort involving deployment of new instrumented moorings (e.g. CIESM, 2002, among others) provided unprecedented valuable time-series of information evidencing the time scales of abrupt changes and short term processes that remained hidden in classical observations.

\section{Ocean-atmosphere coupling}

The first step for dense water formation episodes appears when conditions of upper water homogenity are set (preconditioning phase; Swallow and Caston, 1973). Then, strong cold and dry winds induce intense evaporation forcing an increase of surface water density. In the NW Mediter-
Table 1. Some typical average mid-winter meteorological conditions and fluxes for the NW Mediterranean (from Marshall and Schott, 1999).

\begin{tabular}{lr}
\hline Air temperature $\left({ }^{\circ} \mathrm{C}\right)$ & 8 \\
Water temperature at surface $\left({ }^{\circ} \mathrm{C}\right)$ & 12.5 \\
Wind speed $(\mathrm{m} / \mathrm{s})$ & 15 \\
Precipitation $(\mathrm{mm} / \mathrm{d})$ & 5 \\
Evaporation $(\mathrm{mm} / \mathrm{d})$ & 13 \\
Heat fluxes $\left(\mathrm{w} / \mathrm{m}^{2}\right)$ : & \\
$\quad$ Sensible & -150 \\
$\quad$ Latent & -400 \\
$\quad$ Shortwave radiation & 120 \\
$\quad$ Longwave radiation & -80 \\
Net heat flux & -510 \\
Total buoyancy flux $\left(10^{-8} \mathrm{~m}^{2} / \mathrm{s}^{3}\right)$ & 30 \\
\hline
\end{tabular}

ranean (Fig. 1), strong northerlies are relatively common in mid winter, blowing form the Rhône valley and through the Carcassonne gap in correspondence of typical low pressure systems in the Gulf of Genova (Gascard, 1978). Such forcing (see Table 1 for a summary of mean fluxes and conditions) may act either over the continental shelves, like that of the Gulf of Lions, or over deep open seas, typically the basin east of Catalonia and south of Provence. Over the shelf, surface water is expected to be fresher and lighter than offshore 


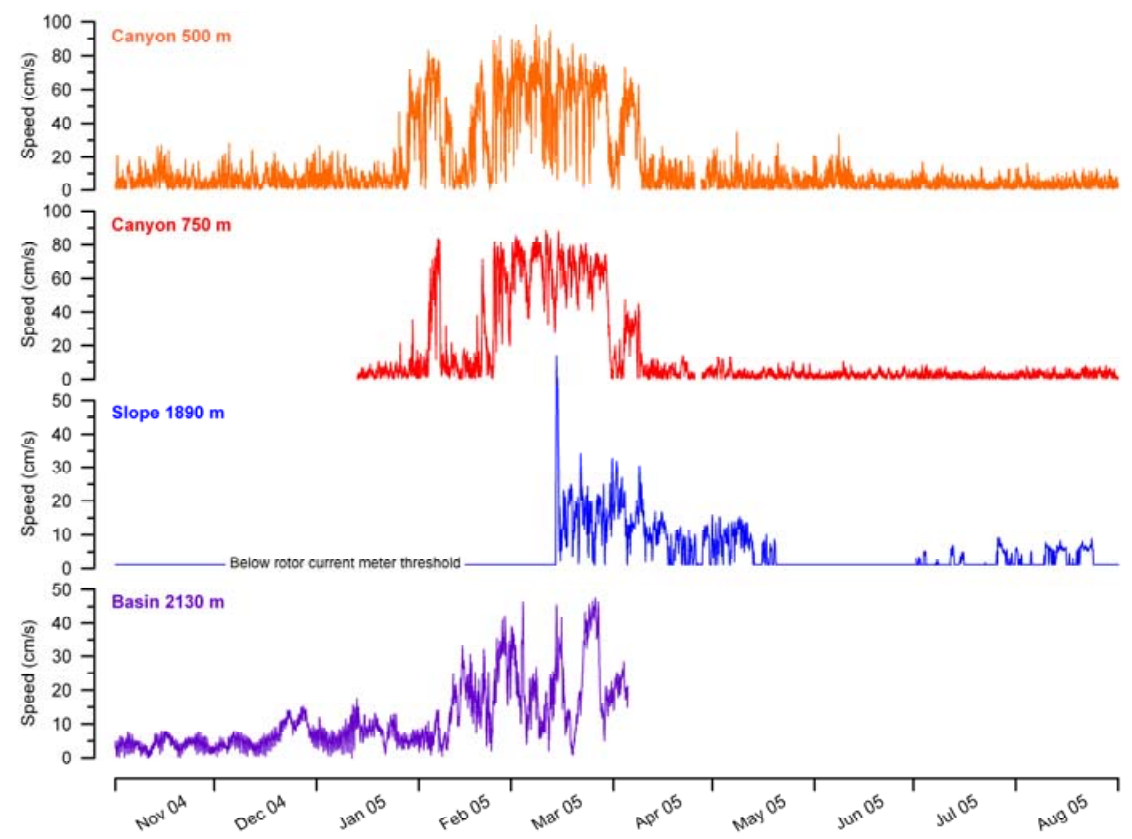

Fig. 2. Time series of currents recorded in winter 2005 by two moorings deployed along the Cap de Creus canyon axis at 500 and $750 \mathrm{~m}$ water depth (point 1 in Fig. 1), the HydroChanges mooring on the Catalan slope at $1850 \mathrm{~m}$ (point 2 in Fig. 1) and the mooring in the central part of the basin at $2130 \mathrm{~m}$ (point 3 in Fig. 1).

because of the river runoff (mainly from the Rhône). Water circulation along the continental margin, geostrophically adapted to the horizontal density gradient, is cyclonic, thus weakening the stratification in the centre of the NW Mediterranean basin (Allain, 1960; Millot, 1999). Cooling is more effective over the shelf, because the heat content of a much shallower water column is lower. Once water density over the shelf is high enough, the bottom water overflows and violently sinks along the slope to reach a layer of equal density, eventually the bottom. This occurs in relatively narrow areas and through submarine canyons, generating what has been called a dense water cascading event (Fieux, 1974). Over the deep open seas, in the central part of the NW Mediterranean basin, dense water sinks almost vertically in "chimneys" or "plumes" (MEDOC, 1970). The horizontal scale of these plumes is only about $1 \mathrm{~km}$ and sinking can reach vertical velocities of more than $10 \mathrm{~cm} / \mathrm{s}$ for very short time periods of several hours (Schott and Leaman, 1991). In such open sea winter convection events, the dense water can sink some $800 \mathrm{~m}$ within a matter of hours and may reach the bottom level, $>2500 \mathrm{~m}$ deep, within a couple of days (Voorhis and Webb, 1970; Schott and Leaman, 1991). This process is accompanied by a compensating rise of water from great depth on all sides (Marshall and Schott, 1999). Latent heat loss by intense evaporation also has a counterpart in the atmosphere enhancing cyclogenesis (Colacino, 1992).
A key role on the instability of the upper layer during the process is played by the Levantine Intermediate Water (LIW) as a water mass of slightly higher salinity, typically found between 250 and $600 \mathrm{~m}$, brought to the upper layers by the first step of the convection, and mixing with the "resident" water (Tchernia, 1958). The presence of an intermediate water of slightly higher salinity seems to be an important ingredient in open sea deep convection processes also in other parts of the world ocean such as polar regions (Gascard, 1991).

There are then two mechanisms of dense water formation competing in the NW Mediterranean. One is open sea deep convection in the central region off the Gulf of Lions (MEDOC, 1970) and the other is slope cascading of dense shelf waters along the continental slope of the western half of the NW Mediterranean (Bougis and Ruivo, 1954; Fieux, 1974; Durrieu de Madron, 2005). The dense waters produced by this latter mechanism typically are less saline and cooler than those originated by open sea deep convection, and sometimes they do not lose enough buoyancy to reach the bottom of the basin and remain above the LIW layer. In this case, slope cascading contributes to the Western Intermediate Water (WIW), a local intermediate water mass lying over the LIW (Salat and Font, 1987).

\section{Recent observations}

During the last years, several moorings deployed in the areas of dense water formation (Fig. 1) have shown the effects of 


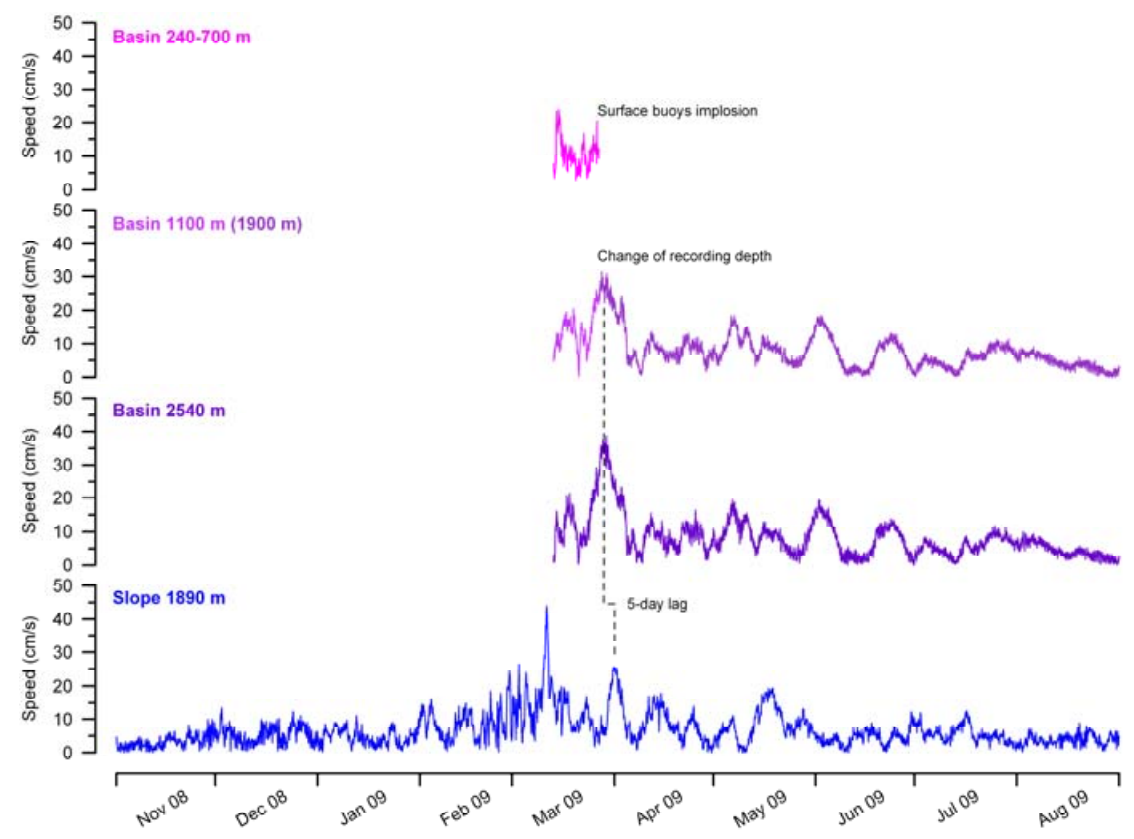

Fig. 3. Time series of currents recorded in winter 2009 by a mooring in the central part of the basin (point 3 in Fig. 1) at several depths: between 240 and $700 \mathrm{~m}$ before the implosion of the surface buoys, at $1100 \mathrm{~m}$ before and $1900 \mathrm{~m}$ after the line sunk, and at $2540 \mathrm{~m}$ (see text for details), and by the HydroChanges mooring on the Catalan slope at $1890 \mathrm{~m}$ (point 2 in Fig. 1).

violent sinking of waters either in open sea locations and over the continental slopes (Figs. 2 and 3). The recorded timeseries have been crucial to obtain a more detailed picture of the dense water formation event succession both from the Gulf of Lions shelf and from open sea regions. They have shown the time scales involved in the processes, being this information complementary to that gathered during cruises. Typically, the deep layers are characterised by slow motion and almost no variability in temperature and salinity. However, when dense water formation takes place, they start to become much more unstable. This behaviour coincides with the phase of violent sinking and lasts during the whole spreading phase, sometimes until the end of the spring season.

A good example of such a situation can be found in winter 2005, when intense dense water formation and deep cascading were observed along the Catalan slope with velocities of nearly $80 \mathrm{~cm} / \mathrm{s}$ over the bottom (Font et al., 2007; Fig. 2). The effects on the sea bed were evident with clear erosion and sediment resuspension (Canals et al., 2006; Puig et al. 2008). The increased downward particle fluxes in the basin (Palanques et al., 2009) generated a bottom nepheloid layer covering the entire NW Mediterranean in few months that has lasted at least until 2009 (Puig et al., 2009).

More recently, in winter 2009, deep open sea convection also occurred but not deep cascading. A long instrumented mooring located in the basin (Fig. 1) was severely bent due to strong currents, moving progressively the upper buoys initially located at less than $200 \mathrm{~m}$ depth down to at least
$800 \mathrm{~m}$ and causing their implosion. The upper part of the mooring line sunk several hundreds of meters (Figs. 3 and 4). These observations show a dramatic episode of a strong SW current reaching $>30 \mathrm{~cm} / \mathrm{s}$ over the entire water column ( $>2000 \mathrm{~m}$ ) from 21 March to 4 April but also show relatively high velocities before this event and later. This episode was also recorded in the mooring deployed on the lower Catalan slope (Fig. 1) 5-6 days later. Taking into account the distance between the two sites $(\sim 125 \mathrm{~km})$ the perturbation propagated southwestwards at nearly $30 \mathrm{~cm} / \mathrm{s}$, a speed and direction comparable to that measured in the mooring. CTD data obtained during an oceanographic cruise carried out in the region from 8 to 22 March (not shown) also evidenced active and recent events of dense water formation with very homogeneous density profiles (some with differences in potential density lower than $0.01 \mathrm{~kg} / \mathrm{m}^{3}$ between surface and $2500 \mathrm{~m}$ ). The strong currents and large volumes of transported water involving the entire water column including the deepest layers would be consistent with strong flows that compensate the deep sinking, as proposed by Salat et al. (2007), in a not completely described mechanism. A preliminary analysis of the currents recorded by the ADCP mounted on the hull of the ship during the above mentioned cruise has also shown patches of strong currents $(>30 \mathrm{~cm} / \mathrm{s})$ over sections $(\sim 10 \mathrm{~km})$ of the ship track. Contemporary satellite images also confirm the complex submesoscale structure with small eddies covering the area. 


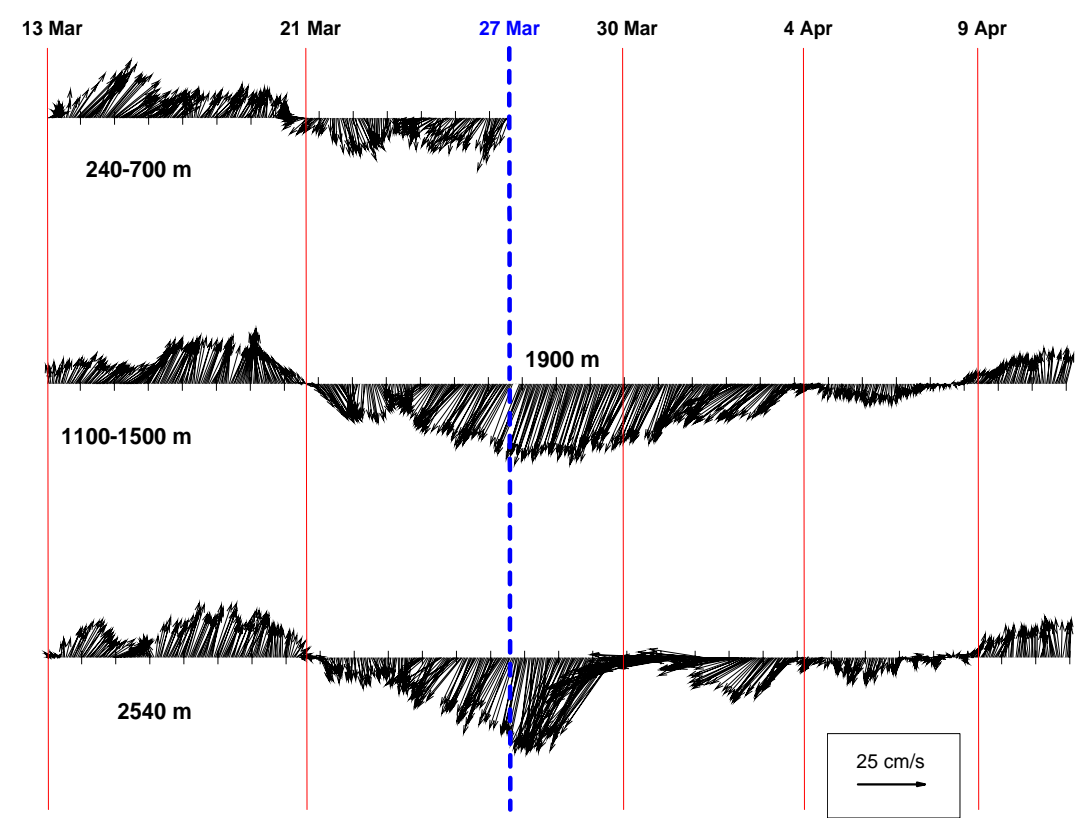

Fig. 4. Stick plot diagrams of the currents recorded by the mooring in the central part of the basin (point 3 in Fig. 1) as in Fig. 3 , from 13 March to 12 April 2009, showing the episode of strong SW currents that bent the mooring line and caused the implosion of the upper buoys on 27 March (see the text for details).

\section{Deep sinking and consequences}

The short and violent episodes of cascading and open sea convection of only a few days' duration supply enough water to feed the lower layer and compensate the outflow through the Strait of Gibraltar for several weeks. The rearrangement of the waters after repeated events in few points across the Mediterranean, like those above mentioned, are contributing to maintain the water exchanges with the Atlantic Ocean, the Mediterranean thermohaline circulation and the deep layer ventilation. The overall amount of dense water formed, however, is highly variable from one year to another according to the forcings involved and perturbations of the water circulation (Killworth, 1976; Bryden and Stommel, 1982).

Deep sinking occurs during short periods ranging from 23 days to several weeks. Water flowing downwards is concentrated in small funnels of few $\mathrm{km}$ in diameter during open sea convection (Marshall and Schott, 1999) or small areas of the slope in cascading events. The vertical downward flow can reach more than $10 \mathrm{~cm} / \mathrm{s}$ for very short time periods of several hours and the overall averaged downward flow can easily reach $1000 \mathrm{~m} /$ day (Schott and Leaman, 1991). More recent observations (van Haren et al., 2006) have shown that horizontal spreading of these anomalous dense waters is a rapid process, irrespective of its source, either from open convection or from cascading off the shelf. Large variations in water mass properties and stability induced by small-scale eddies are observed near dense-water formation area. Nearbottom observations show episodic periods of a few days du- ration of high velocities that are associated with eddies or meanders in boundary currents. If extrapolated to the surface, they may transport material rapidly from surface to the bottom of the basin.

According to Testor and Gascard (2006) newly formed deep waters are carried far away from the source region by eddies characterized by an inner core of about $5 \mathrm{~km}$ in radius. These eddies appear as key elements of the open ocean convection processes playing an important role in the spreading phase following deep convection and in the large scale thermohaline circulation.

Tracking the characteristics of the deep waters newly formed in winter 2005 has shown their ability to spread at nearly $800 \mathrm{~km}$ per year, reaching the Gibraltar sill in less than 3 years (Schroeder et al., 2008). Therefore, we can conclude that all these violent phenomena are able to mobilise huge water volumes. Their short time scale contrasts with the large-scale general thermohaline circulation of the Mediterranean basin that is driven by such violent episodes.

\section{Perspectives}

Violent sinking and spreading of newly formed dense water in the Northwestern Mediterranean Sea has been documented in the last years. However, the complete cycle is not yet well understood. There are strong evidences of short pulses of dramatic compensating currents that are not easily observed. An effort should be devoted to submesoscale studies of the 
interactions among the two sources of deep water (the Gulf of Lions shelf and the open-sea basin south of it) and to the direct observations of flows at intermediate layers by means of moored instruments, gliders and surveys from vessels. Some of the recent records from 2009, still not completely analized, can shed new light on these mechanisms. It may be also important to compare these records with concurrent time series of input/output at Gibraltar to detect the effects of dense water formation pulses in the Atlantic Ocean/Mediterranean water exchanges (CIESM, 2009).

Acknowledgements. Canyon time series observations shown in this study were conducted during the EuroSTRATAFORM Program funded by ONR (Contract numbers N00014-04-1-0379); basin time series were collected during the projects EFLUBIO (REN200204151-C02-01/MAR) and FAMOSO (CTM2008-06261-C03-01) funded by the Spanish Research Plan; and slope time series belong to the ICM contribution to the CIESM HydroChanges programme. All the moorings have been set up by the Instrumentation Service of the Institut de Ciències del Mar. The authors would also like to thank C. Llasat for her interest to include seaatmosphere interactions as a new topic in the Plinius Conference, and the comments and suggestions made by A. Mugnai and the anonymous referee that have contributed to improve the manuscript.

Edited by: A. Mugnai

Reviewed by: one anonymous referee

\section{References}

Allain, C.: Topographie dynamique et courants généraux dans le bassin occidental de la Méditerranée, Rev. Trav. Inst. Pêches Marit., 24, 121-145, 1960.

Bougis, P. and Ruivo, M.. Sur une descente des eaux superficielles en profondeur (cascading) dans le sud du Golfe du Lion. Bulletin d'Information du Comité Central d'Océanographie et d'Etude des Côtes, 6, 147-154, 1954.

Bryden, H. L. and Stommel, H. M.: Origin of the Mediterranean outflow, J. Mar. Res., Suppl., 40, 55-71, 1982.

Canals, M., Puig, P., Durrieu de Madron, X., Heussner, S., and Fabres, J.: Flushing submarine canyons, Nature, 444, 354-357, 2006.

CIESM: Tracking long-term hydrological change in the Mediterranean Sea, CIESM Workshop Series, 16, 134 pp., Monaco, 2002.

CIESM: Dynamics of Mediterranean deep waters, No. 38, in: CIESM Workshop Monographs, edited by: Briand, F., 132 pp., Monaco, 2009.

Colacino, M.: Mediterranean meteorology, in: Winds and currents of the Mediterranean basin, Reports of Meteorology and Oceanogrphy, edited by: Charnock, H., Harvard University, 40, 1-38, 1992.

Durrieu de Madron, X., Zervakis, V., Theocharis, A., and Geogopoulos, D.: Comments on "cascades of dense water around the world ocean”, Prog. Oceanogr., 64, 83-90, 2005.

Fieux, M.: Formation d'eau dense sur le plateau continental du Golfe du Lion, Colloq. Internat, du CNRS sur la formation des eaux océaniques profondes, 215, 165-189, 1974.
Font, J., Puig, P., Salat, J., Palanques, A., and Emelianov, M.: Sequence of hydrographic changes in NW Mediterranean deep water due to the exceptional winter of 2005, Sci. Mar., 71(2), 339346, 2007.

Furnestin, J.: Hydrologie de la Méditerranée occidentale: Golfe du Lion, Mer Catalane, Mer d'Alboran et Corse Orientale, Rev. Trav. Inst. Pêches marit., 24, 5-119, 1960.

Gascard, J. C.: Mediterranean deep water formation, baroclinic instability and oceanic eddies, Oceanol. Acta, 1(3), 315-330, 1978.

Gascard, J. C.: Open ocean convection and deep water formation revisited in the Mediterranean, Labrador, Greenland and Weddell Seas., Elsev. Oceanogr. Series, 57, 157-181, 1991.

Herrmann, M. and Somot, S.: Relevance of ERA40 dynamical downscaling for modeling deep convection in the Mediterranean Sea, Geophys. Res. Lett., 35, L04607, doi:10.1029/2007GL032442, 2008.

Hopkins, T. S.: Physical processes in the Mediterranean basins, in: Estuarine transport processes, edited by: Kjerfve, B., Univ. of South Carolina Press, 7, 269-310, 1978.

Killworth, P. D.: The mixing and spreading phases of MEDOC I, Progr. Oceanogr., 7, 59-90, 1976.

Lacombe, H., Gascard, J. C., Gonella, J., and Bethoux, J. P.: Response of the Mediterranean Sea to the water and energy fluxes across its surface, on seasonal and interannual scales, Oceanol. Acta, 4(2), 247-255, 1981.

Leaman, K. D. and Schott, F.: Hydrographic structure of the convection regime in the Gulf of Lions, winter 1987, J. Phys. Oceanogr., 21, 575-598, 1991.

Marshall, J. and Schott, F.: Open-ocean convection: Observations, theory and models, Rev. Geophys., 37, 1-64, 1999.

Millot, C.: Circulation in the western Mediterranean Sea, J. Marine Syst., 20, 423-442, 1999.

MEDOC Group: Observations of formation of deep water in the Mediterranean Sea, 1969, Nature, 227, 1037-1040, 1970.

Palanques, A., Puig, P., Latasa, M., and Scharek, R.: Deep sediment transport induced by storms and dense shelf water cascading in the northwestern Mediterranean basin, Deep-Sea Res. I, 56, 425434, 2009.

Puig, P., Palanques, A., Orange, D. L., Lastras, G., and Canals, M.: Dense shelf water cascades and sedimentary furrow formation in the Cap de Creus Canyon, northwestern Mediterranean Sea, Cont. Shelf Res., 28, 2017-2030, 2008.

Puig, P., Palanques, A., Font, J., Salat, J., Latasa, M., Scharek, R.: Interactions between open-sea convection and shelf cascading dense waters in the formation of the Western Mediterranean Deep Water, in: CIESM Workshop Monographs No. 38 "Dynamics of Mediterranean Deep Waters", edited by: Briand, F., 81-89, 2009.

Salat, J., Emelianov, M., and López-Jurado, J. L.: A typical Western Mediterranean Deep Water formation during winter 2005, Rapp. Comm. Int. Mer Médit., 38, 197, 2007.

Salat, J. and Font, J.: Water mass structure near and offshore the Catalan Sea during winters of 1982 and 1983, Ann. Geophys., 5B(1), 49-54, 1987.

Schott, F. and Leaman, K.: Observations with moored acoustic Doppler current profilers in the convection regime in the Gulf of Lions, J. Phys. Oceanogr., 21, 558-574, 1991.

Schroeder, K., Ribotti, A., Borghini, M., Sorgente, R., Perilli, A., and Gasparini, G. P.: An extensive western Mediterranean deep 
water renewal between 2004 and 2006, Geophys. Res. Lett., 35, L18605, doi:10.1029/2008GL035146, 2008.

Swallow, J. C. and Caston, G. F.: The preconditioning phase of MEDOC 69, Part I: Observations, Deep-Sea Res., 20, 429-448, 1973.

Tchernia, P.: L'eau intermédiaire dans le bassin Algéro-Provençal, Bull. Inf. COEC., 10, 19-22, 1958.
Testor, P. and Gascard, J. C.: Post-convection spreading phase in the Northwestern Mediterranean Sea, Deep-Sea Res. I, 53, 869-893, 2006.

Voorhis A. D. and Webb D. C.: Large vertical currents observed in a winter sinking region of the northwestern Mediterranean, Cah. Oceanogr., 22, 571-580, 1970. 